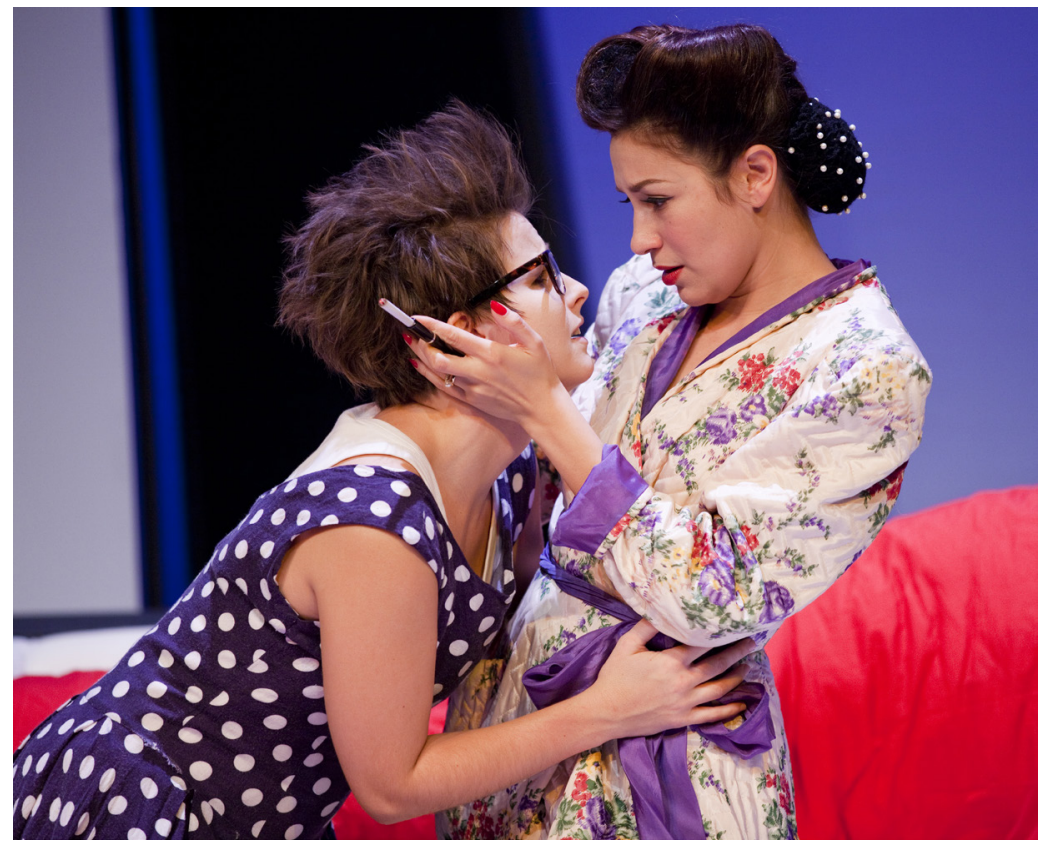

Le nozze di Figaro (W.A. Mozart). Frida Österberg (Cherubino) and Madeleine Ulrici Jostedt (Countess Almaviva), Folkoperan, Stockholm, 20I I. Photographer: Mats Bäcker. Copyright CC-BY-NC-ND: Folkoperan, Stockholm. 


\section{The Touch of Opera, or, Can a Feminist Forgive Anything for a Good Tune?}

I hear the high mezzo voice of the Enigma.

Because it is the Enigma, it doesn't explain itself;

It makes itself heard.

Hélène Cixous, Tancredi Continues

"Still, the fact alone that people of different sexes are brought together in a glamorous auditorium that's the last word in worldly luxury - and then the heathenish disguises, the painted faces, the footlights, the effeminate voices - it all can't help encouraging a certain licentiousness and inducing evil thoughts and impure temptations," Abbé Bournisien bursts out in Flaubert's Madame Bovary. ${ }^{\mathrm{I}}$ Of course, he is right! Since Plato, the sensual and passionate has been a threat for those hostile to the seductiveness of the performing arts. But neither philosophers nor "les Péres" such as Augustine have prevented opera lovers like Emma Bovary from taking pleasure in the opera when "she gave herself up to the lullaby of the melodies, and felt all her being vibrate as if the violin bows were drawn over her nerves." ${ }_{2}$

What then exactly are these mysterious vibrations, the jouissance that the operatic experience evokes? Susan McClary cites Michel Foucault's remark in his History of Sexuality that during the seventeenth century, when opera was established as a public performing art, the West radically started to alter its attitudes toward human erotic behavior. Music is often concerned with stimulating and channeling desire through the medium of sound by using patterns that resemble those of sexuality. "To a greater

How to cite this book chapter:

Rosenberg, Tiina 20I6. The Touch of Opera, or, Can a Feminist Forgive Anything for a Good Tune? In: Rosenberg, Tiina Don't Be Quiet, Start a Riot! Essays on Feminism and Performance. Pp. 2-2 I. Stockholm: Stockholm University Press. DOI: http://dx.doi.org/IO.I6993/baf.a. License: CC-BY 4.0 
extent than ever before, gender and sexuality become central concerns of Western culture in the seventeenth century," McClary writes, "and the new public arts all develop techniques for arousing and manipulating desire, for 'hooking' the spectator." 4 In opera, the dramaturgical movement - from a seductive overture through an interval of building tension, leading to one or more climactic moments, then a repetition of the cycle - seems self-evident. But according to McClary tonal compositions from Bach's organ fugues to Brahms's symphonies “whip up torrents of libidinal energy that are variously thwarted or permitted to gush." ${ }_{5}$

Joseph Kerman's Opera as Drama (I952) analyzed opera as a performed physical exchange between singer and audience. Catherine Clément's Opera, or the Undoing of Women (1979) and Susan McClary's Feminine Endings: Music, Gender, and Sexuality (I99I) are the most influential early feminist studies in the field. In Angel's Cry: Beyond the Pleasure Principle of Opera (I992) Michael Poizat used Lacanian psychoanalysis to ask why opera awakens such passionate desire in its audience. He concludes that opera is a quest for jouissance, the rare and orgasm-like instant of eroticized pleasure induced by the climactic moment of an aria.

Opera research that takes the queer approach celebrates the exuberant qualities of opera and shares Emma Bovary's vibrations. Wayne Koestenbaum's The Queen's Throat: Opera, Homosexuality and the Mystery of Desire (1993) and Sam Abel's Opera in the Flesh: Sexuality in Operatic Performance (I997) analyze opera from a gay male perspective, although the queerness of opera is not confined to gay male desire. Corinne E. Blackmer and Patricia Juliana Smith's anthology, En Travesti: Women, Gender Subversion, Opera (1995), is an attempt to write women's lesbian/queer opera history. Heather Hadlock's “The Career of Cherubino, or The Trouser Role Grows Up” (2000), Naomi André's Voicing Gender: Castrati, Travesti, and the Second Woman in Early Nineteenth-Century Italian Opera (2006), and Judith A. Peraino's Listening to the Sirens: Musical Technologies of Queer Identity from Homer to Hedwig (2006) are all examples of a continued interest in trouser roles and queer musicology in more recent opera studies. ${ }^{6}$ 
This chapter discusses gender and desire in trouser roles and the relationship between the overabundance that characterizes opera and feminist aesthetics. Inspired by Sam Abel's statement, "I can forgive anything for a good tune," it asks if a feminist can forgive anything for a good tune. ${ }^{7}$

\section{Better in pants}

The enduring presence of cross-dressing in Western history and its specific high- and subcultural articulations have been an important part of the discourse of gender studies since the I980s. ${ }^{8}$ Women in classic Western narratives cross-dress for different reasons: to rescue or punish their husbands, to become soldiers, to pose as criminals and outlaws, or to stand up as emancipated, bisexual, or lesbian women. The mystery of androgyny, which is closely connected with the history of bisexuality, is also one of the attractions of cross-dressing. Through the centuries opera has repeatedly made use of cross-dressing in parts originally created for castrati, a repertoire later taken over by female (and male) singers; or performed in trouser roles where a woman sings the part of a man; or in trouser roles where a woman plays a woman who, in accordance with the plot, disguises herself as a man. ${ }^{9}$

Not surprisingly, recent opera studies have focused on trouser roles as opera's lesbian or more broadly queer (in this context meaning unspecified non-heterosexual) heroines. In a trouser role, a woman en travesti (literally "across dress") sings as and looks like (in theory at least) a man, but sounds like, and in fact is, a woman. ${ }^{\text {I0 }}$ The pants, however, do not very convincingly root the female performer's "male" status in a man's genital and libidinal economy. The mimetic function of trouser roles is a masculine one: the cross-dressing woman is only thinkable in relation to the masculinity she represents. Male characters in opera (and representations in general) are universal precisely because they are male. The only way a female character can achieve universality is to transcend her gender. Put simply, men can be men but women, in order to become significant, have to become something more than women.

Blackmer and Smith point out that the trouser role tradition leads to a number of questions that many have contemplated but 


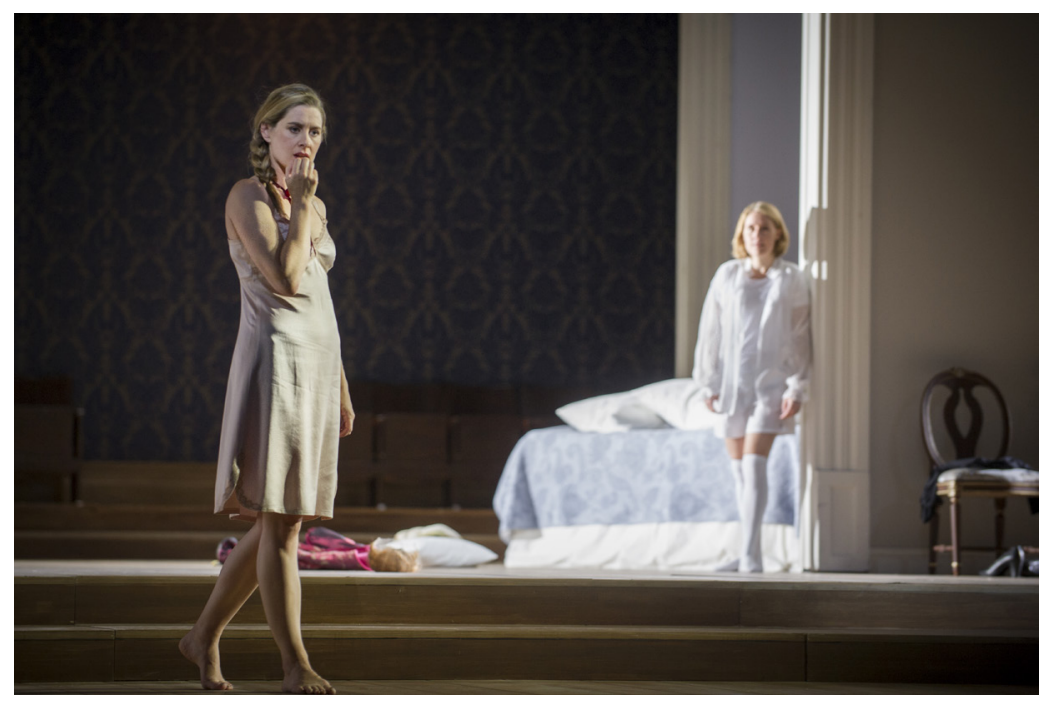

Der Rosenkavalier (Richard Strauss). Malin Byström (Marschallin) and Anna Stéphany (Octavian), Royal Opera, Stockholm, 20 I 5 . Photographer: Alexander Kenney. Copyright CC-BY-NC-ND, Royal Opera, Stockholm.

few have dared to answer. Whether operatic cross-dressing is merely another layer of disguise, or whether it is a revelation of what some audience members and performers have known all along is an open question. ${ }^{\text {II }}$ Gertrud Lehnert, who has written on cross-dressing women in literature, states that the cross-dressing disguise activates the myth of androgyny as human perfection, makes same-sex desire visible, and heightens male pleasure by temporarily lifting a woman up to the level of a man, but in the end dropping her back into her "proper" place. ${ }^{\mathrm{I} 2}$ The desire for a cross-dressing woman depends on what the spectator wants to see: a woman, a man, or an androgynous, gender-unspecific character. The trousers are, however, a powerful phallic sign, and the audience and performers are all asked to suspend disbelief and accept the gender signal of the clothing for "all-male" trouser roles like Cherubino (Le nozze di Figaro) and Octavian (Der Rosenkavalier). The underlying cultural imperative, as Teresa de Lauretis observes, is that the hero must be male, regardless of the gender of the text-image. ${ }^{\text {I3 }}$ 


\section{Opera and sexuality}

Abbé Bourisien's moral qualms about effeminate voices in the quotation from Madame Bovary cited earlier, suggests the potential gender elasticity of opera. Emma Bovary is still safely heterosexual; the priest can be certain of this. But as far as opera is concerned, he has reason to be worried. Through the castrati and trouser roles, the opera expresses a gender-flexible eroticism. Opera is, in Eve Kosofsky Sedgwick's view, queer - not necessarily homosexual per se, but standing in opposition to mainstream, normalized constructions of desire. This queerness is constituted by "the open mesh of possibilities, gaps, overlaps, dissonances and resonances, lapses and excesses of meaning when the constituent elements of anyone's gender, of anyone's sexuality aren't made (or can't be made) to signify monolithically." ${ }^{4}$

In the tradition of trouser roles, the dissonant juxtaposition between the signifier and the signified, and the sexual tension that it generates, is what constitutes the object of desire. The tradition, which reads trouser roles as male, and definitely straight, may not be as hard for audiences - and performers - to swallow as one might at first think. In fact, the transgressive, conspicuous act of crossdressing has long been completely "normalized" on stage. Even in operas like Der Rosenkavalier (I9II) and Ariadne auf Naxos (I9I6), in which trouser roles are distinctly presented as bisexual/ lesbian, the audience is supposed to read the singers as "men." "s Octavian in Rosenkavalier and the Composer in Ariadne, both cross-dressed mezzo-sopranos, make use of the female voice and act out the narrative in trousers, hardly disguising the female body and voice. The queerness of these operas is so explicit that, compared to most classic narratives where audiences are unlikely to get a glimpse of anything queer, those viewing Rosenkavalier and Ariadne have a hard time heterosexualizing an obviously queer narrative. ${ }^{16}$

Kurt Pahlen, editor of the complete text edition of Der Rosenkavalier, gives the standard explanation of Octavian's gender: "Many a person unschooled in music who comes to see Rosenkavalier may find it strange that the title role of the young Octavian is sung by a female voice." ${ }^{17}$ In other words, the eye and body of the musically uneducated (read: a queer person) catches 


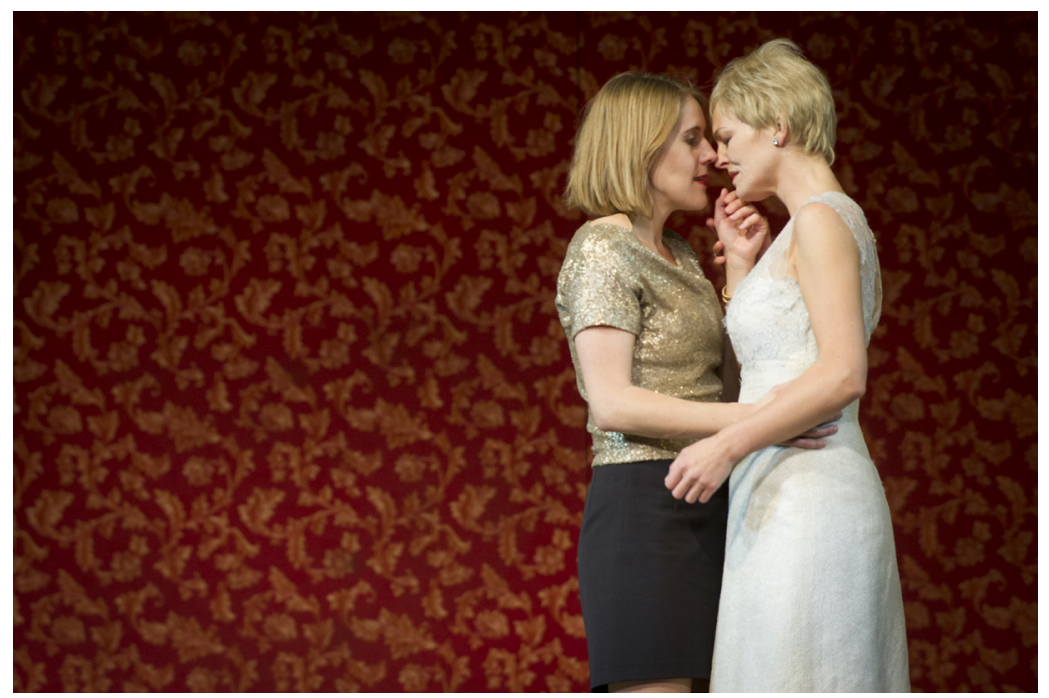

Der Rosenkavalier (Richard Strauss). Anna Stéphany (Octavian) and Elin Rombo (Sophie), Royal Opera, Stockholm, 20I 5. Photographer: Alexander Kenney. Copyright CC-BY-NC-ND, Royal Opera, Stockholm.

the essential presentation of the body - the female - while the musically educated (read: non-queer) eye catches the "correct" gender - the male. Does gender matter, and who now has the ideological power to decide it?

\section{Opera as body genre}

The aspect of music that is most difficult to explain, according to McClary, is its "uncanny ability to make us experience our bodies in accordance with its gestures and rhythms." ${ }^{18}$ As stated in the Introduction to this volume, theatre as performed genre can be defined as any classic verbal or musical text that exists in live execution by performers. The work does not come into being until it is made actual by performers. The body of the performer is the authorial voice of any performed genre. Roland Barthes points out that "the erotic function of the theatre is not accessory, for the theatre alone of all the figurative arts (cinema, painting) presents the bodies and not their representation." 19 Theatrical bodily presentation, the performer's aura, in Walter Benjamin's words, has 
the authorial power over the narrative. The story tells you one thing, the body something else. Barthes's distinction reminds us that logos is not in command on stage.

Theatrical presentation eroticizes the body of the performer, but the spectator never perceives the body through visuals alone. Opera intensifies this experience through vocality. Opera audiences are not only fascinated by voices but also actively participate in the performance through their physical presence in the same auditorium with the singers and by their applause and cheers. Opera performers are not primarily engaging with each other; they are directly addressing the audience. This might be explained as a practical necessity, as their voices might otherwise not carry over the orchestra. However, opera lovers do not think of it that way. They feel caressed, even penetrated, by the voices. Emma Bovary imagines that the tenor on stage really is gazing at her - as he well may be. Her passion is so great that she longs to rush into his arms. Historically, she is right. Actors and singers have always primarily faced the audience. The realistic acting style in which characters focus on each other dates from the nineteenth century theatre.

"Why does an opera performance feel so much like sex?" asks Abel. His answer is that opera feels like a sexual act because it is a sexual act. He is not thinking of Freud's notion of sublimation as metaphorical or vicarious sex, an intellectual reenactment or contemplation of pleasurable sensations. ${ }^{20}$ There is nothing vicarious about opera's sensuality, Abel states. The erotics of opera do not necessarily take place between the characters on stage but between the singers and the audience, mediated by the voice, as the example of Emma Bovary shows.

The term body genre is used by Linda Williams to describe films whose excessive displays of emotion generate physical sensations in the audience. ${ }^{21}$ She sees body genre as a subcategory of melodrama, a "filmic mode of stylistic and/or emotional excess that stands in contrast to more 'dominant' modes of realistic, goal-oriented narrative.” ${ }^{22}$ Williams's notion of melodrama and body genres seems, as Judith A. Peraino has written, almost tailor-made for opera. ${ }^{23}$ The melo(s) in melodrama indicates the excess of melody - a result of emotional expression so extreme as to exceed the bounds of speech and enter the realm of song. Williams 
is referring to the specific form of excess which opera lovers crave from their preferred art form: elements of direct or indirect sexual excitement and rapture that even infuse the pathos of melodrama.

\section{Women and opera: Victims or envoicing?}

The feeling of being seduced and carried away from every critical discourse is an uneasy one for a feminist. But sometimes even a feminist needs a break from Verfremdung, and in this regard the feminist discourse about women and opera offers two possibilities. The first sees women as victims of the opera, and the second views opera as envoicing women. ${ }^{24}$

Opera is an art form with many gender-related anxieties. Women are the victims of the opera, argues Catherine Clément. She analyzes opera as a ritual of sacrifice staged by male librettists, composers, directors, conductors, and opera managers. "Opera is not forbidden to women," Clément writes. "Women are its jewels, the ornament indispensable for every festival. No prima donna, no opera. But the role of the jewel, a decorative object, is not the deciding role; and on the opera stage women perpetually sing their eternal undoing. The emotion is never more poignant than at the moment when the voice is lifted to die." ${ }_{25}$ Opera is a male paradigm par excellence. The women, however independent and active they may seem, play a male game and are finally sacrificed. Clément lists an array of plots taken from what she calls "the dead women's opera," an unbroken litany of women punished for daring to desire and to act. McClary has stated that if Clément's catalogue is depressingly redundant, so are the schemata of dominant opera narratives. ${ }^{26}$

The phallic power of the gaze has been extensively commented upon in feminist criticism and theory. Women on stage do not represent the subject position - their desire is not symbolized in patriarchal culture, nor do the dynamics of their desires operate within the theatrical experience. "The audience becomes the male subject, exiled in the system of theatrical representation and driven by unfulfilled desire," writes Sue-Ellen Case. ${ }^{27}$

The rather discouraging view taken by Clément and other feminists is founded on strong evidence. Clément, however, is 
categorical. She discusses the female characters in so-called "serious opera," but neglects comic operas and does not see the gender-crossing potential of trouser roles. Female characters in comic operas and many women in trouser roles take matters into their own hands, managing to end up with a partner whom they have freely chosen, rather than one assigned to them by someone else. ${ }^{28}$

Carolyn Abbate presents the envoicing discourse: a woman, through the power of her voice, transcends her gender. ${ }^{29}$ The castrato voice and, later, women's voices have been essentials of opera since its beginnings, and have served to envoice the marginalized. Abbate is inspired by Barthes's essay "The Grain of the Voice" in which he proposes the rebirth of the author "inside" of the work of art. Barthes eliminates a specifically male position (the author logos), supplanting it with an overtly female and musical force (the voice)..$^{30}$ The experience of the voice, not the musical notation, transcends its "masculinity." The distinction Barthes makes between the presentation and the representation of the body in performance strongly suggests that all performance is characterized by corporeality and instability - something a narrative cannot entirely control.

For Barthes, listening is an active erotic act, not a passive receptive one. "The voice is that space which can hardly be placed, in which body and language come together, yet without becoming one," comments Doris Kolesch. ${ }^{31}$ In this combination of the abstract and corporeal, Barthes locates an art form without the system of signifier/signified. The grain of the voice is the materiality of the body speaking its mother tongue. ${ }^{32}$

Barthes's alignment of the female with discursive language and with music sounds familiar. As Abbate points out, associating music with the feminine is pervasive in feminist theory, as in Julia Kristeva's notion of the chora as an enveloping but non-linguistic sound. This is so much so that many writers take for granted that what is spoken by the pre-linguistic female or maternal voice is "music." 33 This French poststructuralist position - what Alice Jardine has called "the-woman-in-effect" - does not clearly express what is actually meant by feminine. ${ }^{34}$

Luce Irigaray sees the feminine of the philosophers as an attempt at colonization that once more pushes women from cultural space; 
male theorists have become better at being women than women are. Abbate asks if a feminine voice within a work of art can ever be defined, other than as something negative that can only be heard to sing after a real "author" is methodically eliminated from what we read or hear. ${ }^{35}$ Barthes would probably respond that the body speaking its mother tongue is rather a metaphor for the other meaning-creating locations for which he is looking. The voice is something specific in itself, a vibration beyond the classic linguistic sign, deeply rooted in the human body. ${ }^{36}$ Nevertheless, the body is still a gendered one.

\section{The caressing touch of the voice}

Michel Foucault and Judith Butler address the body and its pleasures as the target of technologies of surveillance and control, but both have almost nothing to say about those bodies, or the pleasures, that are being controlled. As their critics complain, this creates a disembodied, unstable, or empty space around which to frame any alternative understandings or politics. ${ }^{37}$

In her extravagant poetics of the I970s, Irigaray sought to embrace all the metaphors of the feminine in order to construct a language for the feminine body, that is, to explore the "distinction of the sexes in terms of the way they inhabit or are inhabited by language." ${ }^{8}$ Lynne Segal observes that Butler's thoughts are in some ways reminiscent of those of Irigaray who, in declaring the unrepresentability - and hence repudiation - of women in phallogocentric discourse, proposes a strategy of "disruptive excess." ${ }_{39}$ Irigaray argues that by deliberately taking on the feminine role, women "convert a form of subordination into an affirmation, and thus begin to thwart it." $4 \circ$ However, Butler is critical of Irigaray because she does not use this strategy as a type of parody, a subversive mimesis. Irigaray dares to metaphorically characterize a specifically feminine pleasure, most memorably in the essays "This Sex Which Is Not One" and "When Our Lips Speak Together." ${ }^{4 \mathrm{I}}$ Her formulation of a positive theory of femininity is not an aberration, as Naomi Schor claims in her essay "This Essentialism Which Is Not One." ${ }^{22}$ It is rather the logical extension of her deconstruction of the specular logic of saming.

According to Irigaray, the predominance of the visual, and the discrimination and individualization of form, is particularly 
foreign to female eroticism. Women take far more pleasure in touching than looking, Irigaray states, and her entry into a dominant scopic economy again signifies her consignment to passivity. But the voice is not limited to iconic models of mimesis. The voice, not the gaze, has the quality of touching someone (toucher de la caresse). The female voice replaces the male author in a single cutting stroke, filling it not by an androgynous voice but with a female who has been artificially constructed for this purpose by the one who is singing, the performer.

Women's paired like-voices, "two equal voices rubbing up against each other," produce in Elizabeth Wood's words a border crossing, a bivocal Sapphonic effect primarily in travesty and transvestic duets formerly sung by castrati. ${ }^{43}$ The castrato, argues musicologist Joke Dame, voiced sexual difference by going against the grain of a dominant oppositional female-male pairing. ${ }^{44}$ The modern substitution of male tenors and female sopranos cannot match the interchange and interweaving of body, timbre, and pitch produced by castrati because their registers are too far apart. McClary points out that when we listen to two female like-voices, we experience female desire differently. This notion comes very close to Irigaray's account of women's eroticism in terms of "two lips in continuous contact." 45

Could female sexuality, then, be positively represented by the metaphor of these "two lips," as Irigaray suggests? The two lips, while never one, are also never strictly two. They are simultaneously one and two. Where one identity ends and another begins remains unclear. This paradoxical image defies binary categories and forms of classification, being both inside and outside, one and two, genital and oral. The icon of two lips is not a truthful image of female anatomy but a new emblem by which female sexuality can be positively represented. ${ }^{46}$ For Irigaray the problem is not the experience or recognition of female pleasure, but its representation, which actively constructs women's experience of their corporeality and pleasures.

Many trouser roles for both mezzos and sopranos, as Wood finds, are relatively free of warm "womanly vibrato." The extreme range in one female voice, from richly dark deep chest tones to piercingly clear high falsetto, and its break at the crossing of registers, is the effect she calls sonic cross-dressing, "a merging rather 
than splitting of butch authority and femme ambiguity, an acceptance and integration of female and male." 47 Wayne Koestenbaum suggests that the break between registers (fancifully called $i l$ ponticello, the little bridge) is the place within one voice where the split between male and female occurs, and that failure to disguise this gendered break is, like falsetto, fatal to the art of 'natural' voice production. "The register line, like the color line, the gender line, or the hetero/homo line," he writes, "can be crossed only if the transgressor pretends that no journey has taken place." ${ }_{48}$

According to Wood, the Sapphonic voice is a transvestic enigma, belonging to neither female nor male as constructed - a synthesis, not a split. Thus, 'Sapphonic voice' becomes a metaphor for the inclusive role-playing entity proposed by Case in her essay "Towards a Butch-Femme Aesthetic." ${ }_{49}$ Wood calls this voice a challenge to the polarities of both gender and sexuality as these have been socially constructed in the form of a stable binary symmetry. The Sapphonic voice suggests that both gender and sexuality are transferable. Since it is a combination of registers, its acoustic effect resists vocal categories and (un)natural polarities. It also confounds simplistic messages about female desire and relationships defined by class, age, sexual status, and identity, both in music and operatic roles conventionally assigned to specific female voices. For listeners, the Sapphonic voice is a destabilizing agent of fantasy and desire. "The woman with this voice," Wood reflects, "this capacity to embody and traverse a range of sonic possibilities and overflow sonic boundaries, may vocalize inadmissible sexualities and a thrilling readiness to go beyond so-called natural limits, an erotics of risk and defiance, a desire for desire itself." ${ }^{\circ} \circ$

\section{Another layer of disguise, or, whose mimesis is this anyway?}

Is the power of musical desire to mimic sympathy precisely the danger Clément has warned against? Historically, women have been denied power in the theatrical apparatus, yet signs of female sexuality have been crucial to the functioning of that sphere. Is mimesis, then, once and for all masculine? Elin Diamond points out that mimesis denotes both the activity of representing and its 
result. It is the impossible double, simultaneously the stake and the shifting sands, order and potential disorder, reason and madness. ${ }^{51}$ Irigaray writes that women should make use of mimesis and mimicry in order to put phallogocentric discourse in motion. Therefore, to play with mimesis is one strategy through which women may take possession of the place of their exploitation through discourse, without allowing themselves to be simply reduced to it. Disruptive excess is one way of doing so.

Opera, being too much of everything, is not a part of theatre realism, or what Diamond calls "mimesis's positivist movement." ${ }^{2}$ The excessive engagement of opera problematizes both mimesis and identification because it offers too much with which to identify. ${ }^{53}$ Since excess is that which overflows boundaries, it has been seen as the space of transvestite desire. ${ }^{54}$ The emphasis on performance, according to the distinction Barthes makes between representation and presentation of bodies, is one element in the undoing of opera's masculinity. The ear is a culpable organ, a symbol of emasculation. 55 The tradition of despising pleasure received through the ear, and condemning it as "tickling," is ancient. "A singer is queer," Koestenbaum writes, "because she presents the ear with unexpected bounty." ${ }_{56}$

When it comes to trouser roles, it may be as simple as Terry Castle has stated: the male persona is only that and no more in narrative fiction. The fact that the body is female and the sound is a woman's voice remains undeniable. ${ }^{57}$ "Bravo! What a fine voice. I didn't know you sang so well!" the Countess says after Cherubino's thrilling arietta "Voi, che sapete che cosa è amor" (You who know what love is) in Figaro. She does not say, "What a beautiful pair of pants you wore!" Even if women cannot be seen, they obviously can be heard.

\section{Notes}

I. Flaubert, Madame Bovary, 255.

2. Ibid., 3 I9.

3. McClary, Feminine Endings, 8.

4. Ibid., 36. 
5. Ibid., I 2-I3.

6. Abel, Opera in the Flesh; André, Voicing Gender; Blackmer \& Smith, En Travesti; Clément, Opera; Hadlock, "The Career of Cherubino, or The Trouser Role Grows Up"; Kerman, Opera as Drama; Koestenbaum, The Queen's Throat; Poizat, Angel's Cry; Peraino, Listening to the Sirens.

7. Abel, Opera in the Flesh, 35.

8. Dekker \& van de Pol, Tradition of Female Transvestism.

9. Blackmer \& Smith, En Travesti, I33.

IO. Strauss, Rosenkavalier, 4 ОI. For this definition of the trouser role syndrome, see Blackmer \& Smith, En Travesti, 5.

I I. Blackmer \& Smith, En Travesti, I I. The term en travesti (often jouer en travesti in French), meaning 'disguised,' comes from the Italian travestire (to disguise), a word that goes back to the Latin trans (across, beyond) + vestire (clothe): to clothe oneself in the garments of the opposite sex. Trouser roles/breeches parts, Hosenrolle, byxroll, housurooli are national terms for travesti roles for women in male clothing.

I 2. Lehnert, Maskeraden und Metamorphosen, 243. See also the same author's Wenn Frauen Männerkleider tragen.

I3. de Lauretis, Alice Doesn't, i I 8-i I9.

I4. Sedgwick, Tendencies. See also Abel, Opera in the Flesh, 65.

I 5. Blackmer \& Smith, En Travesti, I4.

I6. The word queer is here used in the sense of non-heterosexual, following the definition of the term as developed by queer theorists of the I990s. It includes different kinds of sexual possibilities and border crossings between 'normal' and 'pathological,' 'heterosexual' and 'homosexual,' and 'feminine' and 'masculine.'

I7. Strauss, Rosenkavalier, $40 \mathrm{I}$.

I 8. McClary, Feminine Endings, 23.

19. Barthes, Roland Barthes, 83 .

20. Abel, Opera in the Flesh, 23.

2. Williams, "Film Bodies," 3. 
22. Ibid.

23. Peraino; "I am an Opera" in Blackmer and Smith, En Travesti, I 27. 24. See Clément, Opera, 3-23; Abbate, “Opera;” Abbate, In search of Opera.

25. Clément, Opera, 5 .

26. McClary, Feminine Endings, I7 I.

27. Case, Feminism and Theatre, I20.

28. Blackmer \& Smith, En Travesti, 62.

29. Abbate, “Opera." See also Koestenbaum, The Queen's Throat.

30. Roland Barthes, "Le grain de la voix," 238.

3 I. Kolesch, Roland Barthes, I 24.

32. Ibid.

33. Abbate, “Opera," 232.

34. Jardine, Gynesis, 3 I-49.

35. Abbate, “Opera," 232.

36. Kolesch, Roland Barthes, I I 7-I 29.

37. Segal, Straight Sex, I 83 .

38. Ibid., I9 I; Irigaray, This Sex, 78.

39. Irigaray, This Sex, 78; Segal, Straight Sex, I9I. See also Butler, Gender Trouble, 25-26.

40. Irigaray, This Sex, 76.

4 I. Ibid., 205-2 I 8 .

42. Schor, "This Essentialism,” 66.

43. Wood, "Sapphonics."

44. Dame, "Unveiled Voices."

45. McClary, Feminine Endings, 37.

46. Wood, "Sapphonics," 3I. The voice has been described as the duplicate of the vagina. In 1756 Jean Blanchet called the glottis "a 
horizontal cleft terminated by two lips." Robert Lawrence Weer in I948 called the vocal cords "two thick membranes," "two lips," and "little shutters." See Koestenbaum, The Queen's Throat, I60.

47. Wood, “Sapphonics,” 32.

48. Koestenbaum, The Queen's Throat, I67.

49. Case, "Towards a Butch-Femme Aesthetic."

50. Wood, “Sapphonics,” 33.

5I. Diamond, Unmaking Mimesis, v.

52. Ibid., vii.

53. Abel, Opera in the Flesh, 33.

54. Garber, Vested Interests, 28.

55. Koestenbaum, The Queen's Throat, I 83.

56. Ibid., 98.

57. Castle, The Apparitional Lesbian, 230.

\section{Works Cited}

Abbate, Carolyn. “Opera; or, the Envoicing of Women.” In Musicology and Difference: Gender, Sexuality and Music Scholarship, edited by Ruth E. Solie, 225-258. Berkeley: University of California Press, I993.

-In Search of Opera. Princeton: Princeton University Press, 2001 .

Abel, Sam. Opera in the Flesh: Sexuality in Operatic Performance. Boulder, CO: Westview Press, I996.

André, Naomi. Voicing Gender: Castrati, Travesti, and the Second Woman in Early Nineteenth-Century Italian Opera. Bloomington: Indiana University Press, 2006.

Barthes, Roland. Roland Barthes. Paris: Éditions du Seuil, I975; English translation by Richard Howard. London: Macmillan, I995.

Éditions de Seuil, I98I. 
Blackmer, Corinne E. and Patricia Juliana Smith, eds. En Travesti: Women, Gender Subversion, Opera. New York: Columbia University Press, I995.

Butler, Judith. Gender Trouble: Feminism and the Subversion of Identity. New York: Routledge, I990.

Case, Sue-Ellen. Feminism and Theatre. New York: Routledge, I988. . "Towards a Butch-Femme Aesthetic.” Discourse I I (I998): $55-73$.

Castle, Terry. The Apparitional Lesbian: Female Homosexuality and Modern Culture. New York: Columbia University Press, I993.

Clément, Catherine. Opera, or the Undoing of Women. Translated by Betsy Wing with a forward by Susan McClary. London: Tauris Publishers, 1997.

Dame, Joke. "Unveiled Voices: Sexual Difference and the Castrato." In Queering the Pitch: The New Gay and Lesbian Musicology, edited by Philip Brett, Elizabeth Wood, and Gary C. Thomas, I39-I 54. New York: Routledge, I994.

Dekker, Rudolf, and Lotte van de Pol. The Tradition of the Female Transvestism in Early Modern Europe. New York: St Martin's Press, I989.

de Lauretis, Teresa. Alice Doesn't: Feminism, Semiotics, Cinema. Bloomington: Indiana University Press, I984.

Diamond, Elin. Unmaking Mimesis. London: Routledge, I997.

Flaubert, Gustave. Madame Bovary. Paris: Éditions Rombaldi, I 968 [I875]; English translation by Francis Steegmuller. New York: Vintage, I992.

Garber, Marjorie. Vested Interests: Cross-Dressing and Cultural Anxiety. New York: Harper, I993.

Hadlock, Heather. "The Career of Cherubino, or The Trouser Role Grows Up." In Siren Songs. Representations of Gender and Sexuality in Opera, edited by Mary Ann Smart, 67-92. Princeton: Princeton University Press. 2000.

Irigaray, Luce. This Sex Which Is Not One. Ithaca: Cornell University Press, 1985. 
Jardine, Alice A. Gynesis: Configurations of Woman and Modernity. Ithaca: Cornell University Press, I985.

Kerman, Joseph. Opera as Drama. New York: Vintage, 1956.

Koestenbaum, Wayne. The Queen's Throat: Opera, Homosexuality and the Mystery of Desire. London: Penguin, 1993.

Kolesch, Doris. Roland Barthes. Frankfurt: Campus Verlag, I997.

Lehnert, Gertrud. Maskeraden und Metamorphosen. Als Männer verkleidete Frauen in der Literatur. Würzburg: Königshausen and Neumann, I994.

. Wenn Frauen Männerkleider tragen. Geschlecht und Maskerade in Literatur und Geschichte. Munich: Deutscher Taschenbuchverlag, I997.

McClary, Susan. Feminine Endings: Music, Gender, and Sexuality. Minneapolis: University of Minnesota Press, I99I.

Peraino, Judith A. Listening to the Sirens: Musical Technologies of Queer Identity from Homer to Hedwig, Berkeley: University of California Press, 2006.

."I am on Opera: Identifying with Henry Purcell's Dido and Aeneas." In En Travesti: Women, Gender Subversion, Opera, edited by Blackmer, Corinne E. and Patricia Juliana Smith, 99-I3 I. New York: Columbia University Press, 1995.

Poizat, Michael. Angel's Cry: Beyond the Pleasure Principle of Opera. Ithaca: Cornell University Press, I992.

Schor, Naomi. “This Essentialism Which Is Not One.” In Engaging With Irigaray: Feminist Philosophy and Modern European Thought, edited by Carolyn Burke, Naomi Schor, and Margaret Whitford, 57-78. New York: Columbia University Press, I994.

Sedgwick, Eve Kosofsky. Tendencies. Durham, NC: Duke University Press, I993.

Segal, Lynne. Straight Sex: The Politics of Pleasure. London: Virago Press, I994.

Smart, Mary Ann, ed. Siren Songs: Representations of Gender and Sexuality in Opera. Princeton: Princeton University Press, 2000. 
Strauss, Richard. Der Rosenkavalier. Edited by Kurt Palen. Munich: Goldmann Verlag, I980 [I9II].

Williams, Linda. "Film Bodies: Gender, Genre, and Excess.” Film Quarterly 44 (I99I): 2-I3.

Wood, Elizabeth. "Sapphonics.” In Queering the Pitch: The New Gay and Lesbian Musicology, edited by Philip Brett, Elizabeth Wood and Gary C. Thomas, 27-66. New York: Routledge, I994. 